\title{
THE INFLUENCE OF TOBACCO SMOKING ON DENTAL PERIAPICAL CONDITION IN A SAMPLE OF AN ADULT POPULATION OF THE ŁÓDŹ REGION, POLAND
}

\section{KATARZYNA SOPIŃSKA and ELŻBIETA BOŁTACZ-RZEPKOWSKA}

\author{
Medical University of Lodz, Łódź, Poland \\ Department of Conservative Dentistry
}

\begin{abstract}
Objectives: Epidemiological studies show that apical periodontitis (AP), alongside tooth decay, is the most common oral disease. The aim of the study was to evaluate the influence of smoking on the prevalence of AP in the population of the Lódź region, Poland. Material and Methods: The study involved 815 first-time, randomly selected patients reporting to the Central Teaching Hospital of the Medical University of Lodz. The studied group was a systematic sample of the population admitted for treatment in 2016. The study consisted of a questionnaire and a radiological part. Each patient filled out a questionnaire containing demographic data, and an interview regarding smoking and diabetes. The radiological part of the study included the analysis of panoramic radiographs which showed the periapical status, and the presence and quality of root canal treatment. Results: Teeth with $\mathrm{AP}$ were observed more frequently in patients addicted to tobacco either at the time of the study or in the past (group 1) - 7.2\% than in people who had never smoked (group 2$)-5.2 \%(\mathrm{p}<0.0005)$. In the teeth without root canal treatment, AP was observed more frequently in group $1-3.5 \%$ than in group $2-1.9 \%(\mathrm{p}<0.0005)$. A statistically significant difference was found in the percentage of endodontically treated teeth between group 1 and group $2(10.7 \%$ vs. $9.6 \%)(\mathrm{p}=0.017)$. However, no difference was observed in the frequency of AP in the endodontically treated teeth in both groups (37.6\% vs. 35.8\%) ( $\mathrm{p}=0.451)$. Conclusions: Smokers are a group facing an increased risk of AP and, therefore, there is a need for an early detection and treatment of caries and its complications in this group of patients. The multifactorial etiology of AP indicates the necessity to undertake further studies on the effect of smoking on the periapical status. Int J Occup Med Environ Health. 2020;33(1):45-57
\end{abstract}

Key words:

risk factor, smoking, oral health, apical periodontitis, dental care, panoramic radiograph

\section{INTRODUCTION}

Epidemiological studies show that apical periodontitis (AP), alongside with tooth decay, is the most common oral disease. The frequency of inflammatory lesions in the periapical region varies in different populations from $26 \%$ to $80 \%[1-4]$.

Apical periodontitis is associated with the complications of caries and its treatment. The complex mechanism of chronic AP and the accompanying response of the body's immune system cause that not only tooth specific factors predisposing to AP but also non-tooth specific factors, such as general diseases, should be considered. Diabetes is the most frequently mentioned disease affecting the periapical periodontium. The impairment of healing processes is one of its consequences, which may influence the health of periapical tissues. At the molecular level, hyperglyce-

Received: March 27, 2019. Accepted: September 10, 2019.

Corresponding author: Katarzyna Sopińska, Medical University of Lodz, Department of Conservative Dentistry, Pomorska 251, 92-213 Łódź, Poland (e-mail: kasia.sopinska5@gmail.com). 


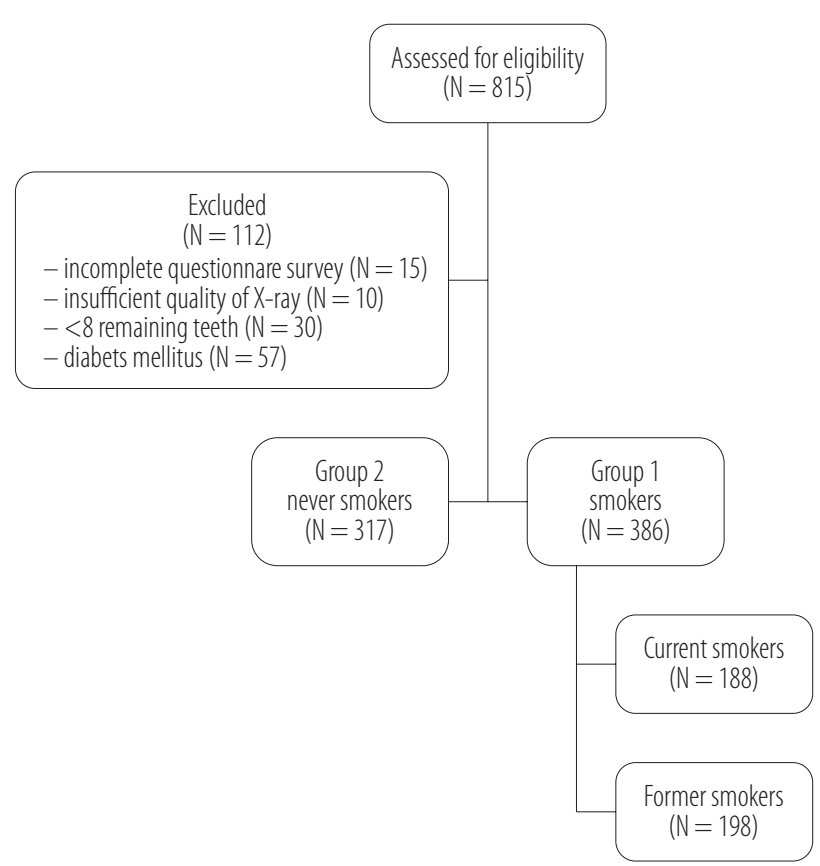

Figure 1. Flowchart showing patient enrolment in the study on the influence of smoking on the prevalence of apical periodontis in the population of the Łódź region $(\mathrm{N}=815)$

mia causes bone resorption, interferes with regeneration processes and suppresses the function of osteoblasts [5]. In many publications, smoking is indicated as one of the factors predisposing to the occurrence of AP $[2,6]$. Tobacco addiction affects the metabolism of bone and connective tissue, as well as impairs the mechanisms of cellular and humoral immunity of the body [7]. Changes in the tissue and vascular metabolism disturb the natural physiological balance between anabolic and catabolic processes [8]. Smoking increases the risk of oral malignant tumors and the failure of implant treatment. It lowers the $\mathrm{pH}$ and buffering capacity of saliva, which may increase a tendency to caries.

The results of studies of various populations have confirmed that the components of tobacco smoke negatively affect the periodontium. The majority of the publications refer to marginal periodontium $[7,9,10]$. However, the literature does not provide sufficient information on the incidence of AP in smokers.
The aim of the study was to evaluate the influence of smoking on the prevalence of apical periodontitis in the population of the Lódź region.

\section{MATERIAL AND METHODS}

The study involved 815 first-time, randomly selected patients reporting to the Central Teaching Hospital of the Medical University (Centralny Szpital Kliniczny Uniwersytetu Medycznego - CSK UM) in Łódź. The study group was a systematic sample of the population admitted to the hospital in 2016. All the patients read the information about the study and gave their written consent to participate in the experiment. The study received a positive opinion of the Bioethics Committee of the Medical University of Lodz, No. RNN/24/14/EC. The patients who did not answer all the questions included in the questionnaire, had $<8$ teeth or suffered from diabetes [5] were excluded from the project. The experiment also excluded persons whose radiographs could not be properly assessed due to the overlapping of anatomical structures (Figure 1).

The study consisted of a questionnaire and a radiological part. Each participant in the experiment was asked to complete the questionnaire. The questionnaire was divided into 2 thematic parts:

- the first one included demographic data, i.e., gender and age,

- the second concerned an interview regarding smoking and diabetes.

Tobacco addicts included patients who smoked at the time of the study or had been smoking at least 10 cigarettes a day in the past for 5 years without interruption [10]. The radiological part of the study included the analysis of panoramic radiographs which were taken at the Imaging Diagnostics Laboratory at the Medical University of Lodz, using a Gendex Orthoralix 9200 digital camera (Dentsply Gendex, Italy).

In the X-rays, the periapical status and the presence and quality of root canal treatment were evaluated, based on 
Table 1. Criteria for assessing the parameters under examination for both groups in the study on the influence of smoking on the prevalence of apical periodontis in the population of the Lódź region $(\mathrm{N}=815)$

\begin{tabular}{|c|c|c|}
\hline Variable & Reference & Assessment criteria \\
\hline Apical periodontitis & $3,11-14$ & $\begin{array}{l}\text { a periapical radiolucent area whose diameter is twice the } \\
\text { width of the periodontal ligament space on the lateral aspect } \\
\text { of a tooth, or the presence of a radiolucent area connected } \\
\text { with the apical part of the root demarcated } \\
\text { from the surrounding tissues with an osteosclerotic border }\end{array}$ \\
\hline Root canal treatment & $3,12,14,15,17$ & $\begin{array}{l}\text { a tooth containing a radiopaque material in the root canal } \\
\text { and/or the pulp chamber }\end{array}$ \\
\hline Quality of root canal treatment & $3,12,14,15,18$ & $\begin{array}{l}1 \text { - correct: filling material in the canals } 0-2 \mathrm{~mm} \\
\text { from the radiographic apex } \\
2 \text { - incorrect: filling material in the canals }>2 \mathrm{~mm} \\
\text { from the radiographic apex, non-homogeneous filling } \\
\text { material in the canals }\end{array}$ \\
\hline
\end{tabular}

the criteria presented in Table 1. Multi-root teeth were classified by taking into account the periapical lesions regardless of the root at which they occurred. Third molars and retained teeth were excluded from the study.

\section{Statistics}

The collected data were analyzed using basic statistical measures. The $\chi^{2}$ independence test was used to compare the groups. In the case of non-homogeneity of the groups according to independent variables, the Mantel-Haenszel $(\mathrm{MH})$ test was used. In the study, a statistically significant level $\mathrm{p}<0.05$ was adopted, and the decision was made based on the p-value calculated using the statistical package (Statistica 12PL). In order to assess the impact of the quality of treatment on the prevalence of periapical lesions, odds ratios (ORs) were calculated and $95 \%$ confidence intervals (CIs) were given.

\section{RESULTS}

A total of 703 patients were submitted to statistical analysis. The study group (group 1) comprised 386 smokers whereas the control group (group 2) included 317 subjects without tobacco addiction. Among the patients classified to group 1, 188 people $(48.7 \%)$ reported that they were current smokers while 198 (51.3\%) had been smoking in the past for 5 years without interruption, at least 10 cigarettes a day [11].

The structure of the studied population, depending on gender and age, is presented in Table 2.

As can be seen from the data in Table 2, the majority of patients in both groups were women $-60.6 \%$ (459), while $39.4 \%$ were men (301). The participants' age ranged 18 91 years. The average age in group 1 was $46.1 \pm 15.3$ years, compared to $45.1 \pm 19.6$ years in group 2. Group 1 was mostly represented by persons of 31-45 years of age (30.6\%), while group 2 by persons $>30$ years of age $(32.8 \%)$.

In the pantomographs, 16213 teeth were assessed. There were no statistically significant differences in the group of smokers and non-smokers regarding the total number of teeth examined, the number of teeth in anatomical groups, and in the maxilla and mandible (Table 3). The basic descriptive statistics for the assessed and missing teeth are presented in Table 4.

The presence of at least one periapical lesion was found in $66.6 \%$ of the patients in group 1 and $55.5 \%$ in group 2 (Table 5). In accordance with the $\mathrm{MH}$ test that indicates statistical non-significance of the calculated common OR ( $p=0.094)$ for the prevalence of AP along age classes, the 
Table 2. Structure of the studied population according to gender and age in the study on the influence of smoking on the prevalence of apical periodontis in the population of the Lódź region $(\mathrm{N}=815)$

\begin{tabular}{|c|c|c|c|c|}
\hline \multirow[t]{2}{*}{ Variable } & \multicolumn{3}{|c|}{$\begin{array}{c}\text { Participants } \\
(\mathrm{N}=703) \\
{[\mathrm{n}(\%)]}\end{array}$} & \multirow[t]{2}{*}{$\mathrm{p}$} \\
\hline & total & $\begin{array}{c}\text { group 1 } \\
(\mathrm{N}=386)\end{array}$ & $\begin{array}{c}\text { group 2 } \\
(\mathrm{N}=317)\end{array}$ & \\
\hline Gender & & & & $<0.005$ \\
\hline women & $426(60.6)$ & $205(53.1)$ & $221(69.7)$ & \\
\hline men & $277(39.4)$ & $181(46.9)$ & $96(30.3)$ & \\
\hline Age & & & & $<0.005$ \\
\hline$<30$ years & $175(24.9)$ & $71(18.4)$ & $104(32.8)$ & \\
\hline $31-45$ years & $187(26.6)$ & $118(30.6)$ & 69 (21.8) & \\
\hline 46-60 years & $163(23.2)$ & $110(28.5)$ & $53(16.7)$ & \\
\hline$>60$ years & $178(25.3)$ & $87(22.5)$ & $91(28.7)$ & \\
\hline
\end{tabular}

Group 1 - smokers; group 2 - subjects without tobacco addiction.

Table 3. Teeth of each type assessed in the examined groups in the study on the influence of smoking on the prevalence of apical periodontis in the population of the Lódź region $(\mathrm{N}=815)$

\begin{tabular}{|c|c|c|c|c|}
\hline \multirow[t]{2}{*}{ Tooth type } & \multicolumn{3}{|c|}{$\begin{array}{c}\text { Teeth } \\
(\mathrm{N}=16213) \\
{[\mathrm{n}(\%)]}\end{array}$} & \multirow{2}{*}{$\mathrm{p}$} \\
\hline & total & $\begin{array}{c}\text { group 1 } \\
(\mathrm{N}=8726)\end{array}$ & $\begin{array}{c}\text { group 2 } \\
(\mathrm{N}=7487)\end{array}$ & \\
\hline Incisor & $5183(32.1)$ & $2826(32.6)$ & $2357(31.4)$ & 0.366 \\
\hline Canine & $2644(16.5)$ & $1442(16.5)$ & $1202(16.1)$ & 0.366 \\
\hline Premolar & $4376(27.1)$ & $2334(26.7)$ & $2042(27.3)$ & 0.366 \\
\hline Molar & $4010(24.3)$ & $2124(24.3)$ & $1886(25.2)$ & 0.366 \\
\hline Maxilla & 7869 (48.6) & $4222(48.4)$ & $3647(48.7)$ & 0.678 \\
\hline Mandible & 8344 (51.4) & 4504 (51.6) & $3840(51.3)$ & 0.678 \\
\hline
\end{tabular}

Explanations as in Table 2.

results of the $\chi^{2}$ independences tests for each age class are shown in Table 6. For the second age class (31-45 years old), a statistically significant dependence between the analyzed variables can be observed (among smokers, the prevalence odds of AP are higher than among non-smokers).

As can be seen from the data in Table 7, AP was found in 1010 teeth assessed. Teeth with periapical lesions were observed more frequently in patients addicted to tobacco either at the time of the experiment or in the past (7.2\%) than in the control group (5.2\%). The difference was statistically significant $(\mathrm{p}<0.0005)$.

In both groups, the periapical lesions were significantly more common in the premolars and molars as compared to the anterior teeth $(p<0.0005)$. The percentage of the 
Table 4. Descriptive statistics for the assessed and missing teeth in the study on the influence of smoking on the prevalence of apical periodontis in the population of the Lódź region $(\mathrm{N}=815)$

\begin{tabular}{|c|c|c|c|c|c|c|}
\hline \multirow{3}{*}{ Parameter } & \multicolumn{6}{|c|}{$\begin{array}{c}\text { Teeth } \\
(\mathrm{N}=19684)\end{array}$} \\
\hline & \multicolumn{3}{|c|}{ assessed } & \multicolumn{3}{|c|}{ missing } \\
\hline & $\begin{array}{c}\text { total } \\
(\mathrm{N}=16213)\end{array}$ & $\begin{array}{c}\text { group 1 } \\
(\mathrm{N}=8726)\end{array}$ & $\begin{array}{c}\text { group 2 } \\
(\mathrm{N}=7487)\end{array}$ & $\begin{array}{c}\text { total } \\
(\mathrm{N}=3471)\end{array}$ & $\begin{array}{c}\text { group 1 } \\
(\mathrm{N}=2082)\end{array}$ & $\begin{array}{c}\text { group 2 } \\
(\mathrm{N}=1389)\end{array}$ \\
\hline Min.-max & $8-28$ & $8-28$ & $8-28$ & $0-20$ & $0-20$ & $0-20$ \\
\hline Lower quartile & 20 & 20 & 21 & 0 & 1 & 0 \\
\hline M & 23.1 & 22.6 & 23.6 & 4.9 & 5.4 & 4.4 \\
\hline $\mathrm{Me}$ & 25 & 24 & 26 & 3 & 4 & 2 \\
\hline Upper quartile & 28 & 27 & 28 & 8 & 8 & 7 \\
\hline SD & 5.5 & 5.4 & 5.5 & 5.5 & 5.4 & 5.5 \\
\hline
\end{tabular}

Explanations as in Table 2.

Table 5. Prevalence of apical periodontitis (AP) in the study on the influence of smoking on the prevalence of apical periodontis in the population of the Łódź region $(\mathrm{N}=815)$

\begin{tabular}{|c|c|c|c|c|}
\hline \multirow{3}{*}{ Group } & \multicolumn{4}{|c|}{$\begin{array}{c}\text { Participants } \\
(\mathrm{N}=703)\end{array}$} \\
\hline & \multicolumn{2}{|c|}{ without AP } & \multicolumn{2}{|c|}{$\mathrm{AP} \geq 1$} \\
\hline & $\mathrm{n}$ & $\%$ & $\mathrm{n}$ & $\%$ \\
\hline Group 1 & 129 & 33.4 & 257 & 66.6 \\
\hline Group 2 & 141 & 44.5 & 176 & 55.5 \\
\hline
\end{tabular}

Chi test $\mathrm{p}=0.003 ;$ MH test (age) $\mathrm{p}=0.094 ; \mathrm{MH}$ test $($ gender $) \mathrm{p}=0.004$.

Table 6. $\mathrm{Chi}^{2}$ independences tests for each age class and the prevalence of apical periodontitis (AP) in the study on the influence of smoking on the prevalence of apical periodontis in the population of the Lódź region $(\mathrm{N}=815)$

\begin{tabular}{|c|c|c|c|c|c|}
\hline \multirow{3}{*}{ Age } & \multicolumn{4}{|c|}{$\begin{array}{l}\text { Participants } \\
(\mathrm{N}=703)\end{array}$} & \multirow{3}{*}{$\mathrm{p}$} \\
\hline & \multicolumn{2}{|c|}{ without $\mathrm{AP}$} & \multicolumn{2}{|c|}{$\mathrm{AP} \geq 1$} & \\
\hline & $\mathrm{n}$ & $\%$ & $\mathrm{n}$ & $\%$ & \\
\hline$\leq 30$ years & & & & & 0.262 \\
\hline group 1 & 47 & 66.2 & 24 & 33.8 & \\
\hline group 2 & 77 & 74.0 & 27 & 26.0 & \\
\hline $31-45$ years & & & & & 0.013 \\
\hline group 1 & 43 & 36.4 & 75 & 63.6 & \\
\hline group 2 & 38 & 55.1 & 31 & 44.9 & \\
\hline
\end{tabular}


Table 6. Chi independences tests for each age class and the prevalence of apical periodontitis (AP) in the study on the influence of smoking on the prevalence of apical periodontis in the population of the Łódź region $(\mathrm{N}=815)$ - cont.

\begin{tabular}{|c|c|c|c|c|c|}
\hline \multirow{3}{*}{ Age } & \multicolumn{4}{|c|}{$\begin{array}{l}\text { Participants } \\
(\mathrm{N}=703)\end{array}$} & \multirow{3}{*}{$\mathrm{p}$} \\
\hline & \multicolumn{2}{|c|}{ without AP } & \multicolumn{2}{|c|}{$\mathrm{AP} \geq 1$} & \\
\hline & $\mathrm{n}$ & $\%$ & $\mathrm{n}$ & $\%$ & \\
\hline $46-60$ years & & & & & 0.973 \\
\hline group 1 & 21 & 19.1 & 89 & 80.9 & \\
\hline group 2 & 10 & 18.9 & 43 & 81.1 & \\
\hline$<60$ years & & & & & 0.598 \\
\hline group 1 & 18 & 20.7 & 69 & 79.3 & \\
\hline group 2 & 16 & 17.6 & 75 & 82.4 & \\
\hline
\end{tabular}

Table 7. Comparison of the prevalence of apical periodontitis (AP) in endodontically treated teeth and non-endodontically treated teeth (the table refers to the teeth) in the study on the influence of smoking on the prevalence of apical periodontis in the population of the Lódź region $(\mathrm{N}=815)$

\begin{tabular}{|c|c|c|c|c|c|c|c|c|c|c|}
\hline \multirow{3}{*}{ Group } & \multicolumn{10}{|c|}{$\begin{array}{c}\text { Teeth } \\
(\mathrm{N}=6213)\end{array}$} \\
\hline & \multirow{2}{*}{$\begin{array}{c}\text { evaluated } \\
\mathrm{n}\end{array}$} & \multicolumn{2}{|c|}{ with $\mathrm{AP}^{\mathrm{a}}$} & \multirow{2}{*}{$\begin{array}{c}\begin{array}{c}\text { without } \\
\text { root canal } \\
\text { treatment }\end{array} \\
\mathrm{n}\end{array}$} & \multicolumn{2}{|c|}{$\begin{array}{l}\text { without root canal } \\
\text { treatment with } \mathrm{AP}^{\mathrm{b}}\end{array}$} & \multicolumn{2}{|c|}{$\begin{array}{l}\text { with root canal } \\
\text { treatment }^{c}\end{array}$} & \multicolumn{2}{|c|}{$\begin{array}{l}\text { with root canal } \\
\text { treatment and } \mathrm{AP}\end{array}$} \\
\hline & & $\mathrm{n}$ & $\%$ & & $\mathrm{n}$ & $\%$ & $\mathrm{n}$ & $\%$ & $\mathrm{n}$ & $\%$ \\
\hline group 1 & 8726 & 624 & 7.2 & 7791 & 272 & 3.5 & 935 & 10.7 & 352 & 37.6 \\
\hline group 2 & 7487 & 386 & 5.2 & 6770 & 129 & 1.9 & 717 & 9.6 & 257 & 35.8 \\
\hline
\end{tabular}

${ }^{a} C^{2}{ }^{2}$ test $\mathrm{p}^{*}<0.0005, \mathrm{MH}$ test 0.005 , common OR estimate $0.779,95 \% \mathrm{CI}: 0.681-0.891$.

${ }^{\mathrm{b}} \mathrm{Chi}^{2}$ test $\mathrm{p}^{*}<0.0005, \mathrm{MH}$ test 0.005 , common OR estimate $0.585,95 \%$ CI: $0.472-0.726$.

${ }^{\mathrm{c}} \mathrm{Chi}^{2}$ test $\mathrm{p}^{*}=0.017$, MH test 0.561 , common OR estimate $0.968,95 \%$ CI: $0.871-1.076$.

${ }^{\mathrm{d}} \mathrm{Chi}^{2}$ test $\mathrm{p}^{*}=0.451$, MH test 0.760 , common OR estimate $0.963,95 \%$ CI: 0.783-1.184.

* Chi ${ }^{2}$ test is conducted to compare the analyzed groups according to the indicated variables.

incisors and canines with periapical pathologies was at a similar level $(3.1 \%$ and $3.0 \%$ in group 1 , and $2.3 \%$ in group 2). In both groups, an approximately 2-fold higher percentage of lesions was observed in the premolars than in the anterior teeth. Also, the percentage of teeth with AP was about twice as high in the molars as in the premolars in both groups. In the study and control groups, AP occurred more often in the maxilla than in the mandible although a statistically significant difference was found only among tobacco addicts. The above data are presented in Table 8.

In the teeth without root canal treatment, the pathologies of the periapical region were significantly more frequently $(\mathrm{p}<0.0005)$ observed among the patients in group $1-$ $3.5 \%$ than in group $2-1.9 \%$.

There was also a statistically significant difference between group 1 and group 2 in the percentage of endodontically treated teeth $(10.7 \%$ vs. $9.6 \%)(\mathrm{p}=0.017)$. 
Table 8. Prevalence of apical periodontitis (AP) according to the type and location of the tooth in the study on the influence of smoking on the prevalence of apical periodontis in the population of the Lódź region $(\mathrm{N}=815)$

\begin{tabular}{|c|c|c|c|c|c|c|}
\hline \multirow{3}{*}{ Variable } & \multicolumn{6}{|c|}{$\begin{array}{c}\text { Teeth } \\
(\mathrm{N}=1010) \\
{[\mathrm{n}(\%)]}\end{array}$} \\
\hline & \multicolumn{2}{|c|}{ total } & \multicolumn{2}{|c|}{ group 1} & \multicolumn{2}{|c|}{ group 2} \\
\hline & $\mathrm{AP}$ & without AP & $\mathrm{AP}$ & without AP & $\mathrm{AP}$ & without AP \\
\hline \multicolumn{7}{|l|}{ Tooth type ${ }^{\mathrm{a}}$} \\
\hline incisor & $143(2.8)$ & & $88(3.1)$ & & $55(2.3)$ & \\
\hline canine & $71(2.7)$ & & $43(3.0$ & & $28(2.3)$ & \\
\hline premolar & $294(6.7)$ & & $180(7.7)$ & & $114(5.6)$ & \\
\hline molar & $502(12.5)$ & & $313(14.7)$ & & $189(10.0)$ & \\
\hline total & $1010(6.2)$ & & $624(7.2)$ & & $386(5.2)$ & \\
\hline \multicolumn{7}{|l|}{ Tooth location ${ }^{\mathrm{b}}$} \\
\hline maxilla & $543(6.9)$ & 7326 (93.1) & $342(8.1)$ & 3880 (91.9) & $201(5.5)$ & $3446(94.5)$ \\
\hline mandible & 467 (5.6) & 7877 (94.4) & $282(6.3)$ & 4222 (93.7) & 185 (4.8) & 3655 (95.2) \\
\hline total & $1010(6.2)$ & $15203(93.8)$ & $624(7.2)$ & 8102 (92.8) & $386(5.2)$ & $7101(94.8)$ \\
\hline
\end{tabular}

a P-value*: total $<0.0005$, Group $1<0.0005$, Group $2<0.0005$.

${ }^{\mathrm{b}}$ Total: $\mathrm{p}^{*}=0.001, \mathrm{OR}^{* *}=0.80,95 \%$ CI: 0.70-0.91; group 1: $\mathrm{p}^{*}=0.001, \mathrm{OR}^{* *}=0.76,95 \%$ CI: 0.64-0.89; group 2: $\mathrm{p}^{*}=0.175$, OR ${ }^{* *}=0.87$, 95\% CI: 0.71-1.07.

* The p-value concerns comparisons inside the groups according to the tooth type and tooth location.

** The OR is a measure of the association between tooth location and the prevalence of AP in the groups.

Table 9. Prevalence of apical periodontitis (AP) according to the quality of the root canal filling in the study on the influence of smoking on the prevalence of apical periodontis in the population of the Lódź region $(\mathrm{N}=815)$

\begin{tabular}{|c|c|c|c|c|c|c|}
\hline \multirow{3}{*}{$\begin{array}{c}\text { Root canal filling } \\
\text { quality }\end{array}$} & \multicolumn{6}{|c|}{$\begin{array}{c}\text { Participants } \\
(\mathrm{N}=1652) \\
{[\mathrm{n}(\%)]}\end{array}$} \\
\hline & \multicolumn{2}{|c|}{ total $^{\mathrm{a}}$} & \multicolumn{2}{|c|}{ group $1^{\mathrm{b}}$} & \multicolumn{2}{|c|}{ group $2^{c}$} \\
\hline & $\mathrm{AP}$ & without AP & $\mathrm{AP}$ & without AP & $\mathrm{AP}$ & without AP \\
\hline Correct & $175(15.7)$ & $940(84.3)$ & $98(15.7)$ & $525(84.3)$ & 77 (15.7) & $415(84.3)$ \\
\hline Incorrect & $434(80.8)$ & 103 (19.2) & $254(81.4)$ & 58 (18.6) & $180(80.0)$ & $45(20)$ \\
\hline Total & $609(36.9)$ & $1043(63.1)$ & $352(37.6)$ & $583(62.4)$ & $257(35.8)$ & $460(64.2)$ \\
\hline
\end{tabular}

${ }^{\text {a }} \mathrm{p}^{*}<0.0005, \mathrm{OR}^{* *}=22.5,95 \% \mathrm{CI}: 17.2-29.4$.

${ }^{\mathrm{b}} \mathrm{p}^{*}<0.0005, \mathrm{OR}^{* *}=23.46,95 \% \mathrm{CI}: 16.4-33.5$.

${ }^{\mathrm{c}} \mathrm{p}^{*}<0.0005, \mathrm{OR}^{* *}=21.56,95 \% \mathrm{CI}: 14.3-32.4$.

* The p-value concerns comparisons inside the groups according to the quality of the root canal filling.

** The OR is a measure of the association between the quality of the root canal filling and the prevalence of AP in the groups.

However, no significant difference in the percentage of endodontically treated teeth with AP was found $(37.6 \%$ vs. $35.8 \%)(\mathrm{p}=0.451)$. The above data are presented in Table 7. 
In both groups, the analysis showed a statistically significant difference in the frequency of AP depending on the quality of root canal treatment. In Group 1, among the teeth with an improperly filled canal, $81.4 \%$ had apical periodontitis, and in group $2-80.0 \%$. However, only $15.7 \%$ of the teeth with correct root canal treatment showed periapical lesions in both groups. The prevalence of AP was higher among patients addicted to tobacco $(\mathrm{OR}=23.46)$ in comparison with those without addiction $(\mathrm{OR}=21.56)($ Table 9$)$.

\section{DISCUSSION}

The study was conducted at the Central Teaching Hospital of the Medical University of Lodz, which provides access to primary and specialized dental care. Patients presenting to the facility form a diverse population in terms of age, education, the place of residence and treatment needs. The hospital enables people from various social groups to be comprehensively treated; therefore, it was considered a suitable place to conduct this analysis.

Diabetic patients were excluded from the experiment because, according to current research, diabetes is one of the risk factors for the prevalence of AP and this could affect the results reliability [5].

The experiment was a cross-sectional study that describes the state of health of the apical periodontium at the time of carrying out the research; therefore, it does not provide information on the dynamics of the disease process [19]. Epidemiological and clinical studies show that inflammatory lesions after endodontic treatment are, in most cases, healed after 2 years from the end of therapy.

In many teeth, as a result of complications of caries or improper root canal treatment, new pathologies develop. This is confirmed by the studies by Petersson et al. [20] regarding the effectiveness of root canal treatment. The authors assessed the state of teeth of the same population after ten years and found that the number of teeth in which inflammatory lesions in the periapical region were healed was comparable to the number of teeth in which new lesions were formed at the same time. Therefore, the statement that cross-sectional studies provide reliable data on the incidence of AP, despite some limitations resulting from the methodology of the experiment, is justified [4,19,21].

In this study, panoramic radiographs were used to assess the periapical status, which are commonly used by dentists for diagnostic purposes and for planning multi-specialist dental treatment. They are also widely applied in epidemiological reviews because commissioning radiological research for scientific purposes only is not accepted in many countries $[13,18,22,23]$. Their advantage is a relatively low dose of radiation, the speed and ease of use, and the fact that all teeth are visible on one X-ray [14,24,25]. Panoramic radiographs also provide information on hard dental tissues, the presence of caries and fillings, root canal treatment and the periapical status [19,26,27]. Tasssöker and Akgünlü [23] underline the high sensitivity (96\%) and specificity (86\%) of this diagnostic method.

According to epidemiological reviews, smoking is one of the factors predisposing to the occurrence of AP [2,6]. Tobacco smoke components have a negative effect on the alveolar bone. Bone regeneration processes are slower and, in the presence of inflammation, they impede the healing process and accelerate the destruction of periodontal structures [5,28].

Most of the data concern the assessment of the impact of smoking on the marginal periodontium, but there is little information about the AP itself. In 2003, Kirkevang and Wenzel [29] examined 613 residents of Denmark and were the first researchers to report that smoking contributes to the increased occurrence of periapical diseases. However, there is no data on this topic in the Polish population.

According to the research conducted by the authors of this paper, apical periodontitis in at least 1 tooth was found more often in smokers $(66.6 \%)$ than in patients without this ad- 
diction (55.5\%). Similar results were obtained in the Spanish population, where at least 1 inflammatory lesion in the periapical region was found in $74 \%$ of smokers and in $41 \%$ of non-addicted people [30]. Peršić et al. [5], studying the Croatian population, also found a higher incidence of AP in smokers $(86.1 \%)$ than in the control group (78.1\%), but this relationship was not statistically significant.

A further detailed analysis was performed with regard to the number of teeth, and not the number of people, because the population similar in numbers may have a different number of teeth. The statistical analysis showed that the examined groups did not differ significantly in terms of the total number of teeth and the number of teeth assessed in anatomic groups.

The prevalence of AP was found to depend on the tooth type. Both among patients addicted to tobacco and those without addiction, AP was more frequently found in the molars (14.7\% and $10.0 \%$, respectively) and premolars (7.7\% and 5.6\%) than in the incisors $(3.1 \%$ and $2.3 \%)$ and canines $(3.1 \%$ and $2.3 \%)$. Literature data also show that AP has been most frequently reported in the molars [12,31,32]. Caries can quickly develop on the occlusal surfaces of the posterior teeth, frequently leading to pulp diseases. The complicated anatomy of the canal system often makes it difficult to carry out the correct endodontic treatment, which results in the development of AP [29]. Epidemiological reviews have also revealed some differences in the prevalence of apical pathologies in the maxilla and mandible [31,33], which was also confirmed by this research. In both groups, the inflammatory lesions occurred more often in the maxilla than in the mandible although the difference was statistically significant only among people addicted to tobacco. According to Murtomaa et al. [34], the anterior teeth of the upper arch are more prone to injuries, which may result in the pulp necrosis and consequent AP.

In the population of the Lódź region, the percentage of teeth with apical periodontitis in the group of smoking pa- tients was significantly higher than among those without addiction (7.2\% vs. 5.2\%). Analyses carried out by SeguraEge et al. [30] in Spain, and by Correia-Sousa et al. [35] in Portugal, also revealed this correlation, although in both countries the values of this parameter were lower: in Spain$5 \%$ and $3 \%$, and in Portugal $-3 \%$ and $1.9 \%$, respectively. Definitely more frequent periapical lesions occurred in Croatia, where $13 \%$ of teeth with changes were observed among smokers and $10 \%$ among non-smokers [5].

Rodriguez et al. [36] investigated this problem in the Swiss population and revealed certain differences in the prevalence of AP, associated with the time of exposure to the components of tobacco smoke. In the group of men who smoked $>1$ packet of cigarettes/day for 10 years, the percentage of teeth with changes was $12 \%$, among those who smoked for a shorter time, it was $5.5 \%$, while in those who had never smoked, the percentage was the lowest and equaled $3.8 \%$.

The present study revealed that in patients addicted to tobacco there was a statistically higher percentage of teeth with apical periodontits without root canal treatment $(3.5 \%)$ than in the control group (1.9\%). These findings may be explained by the results of studies by Palmer et al. [37] on oral hygiene, which revealed a more frequent occurrence of dental plaque in people with addiction. Smoking reduces $\mathrm{pH}$ and saliva buffering capacity, which leads to an increase in the number of cariogenic bacteria Streptococcus mutans and Lactobacillus acidophilus. A thicker biofilm layer increases the susceptibility of tooth tissues to caries, which is one of the main risk factors for AP $[5,38,39]$.

Bergström et al. [9] conducted a questionnaire survey, as well as a clinical and radiological examination in 257 musicians and found a higher prevalence of periodontal diseases in people with addiction. The analysis also showed a greater atrophy of the alveolar bone in those who smoked for at least 15 years. Rudziński and Banach [10] are also of the opinion that the components of tobacco smoke negatively affect the periodontium and cause a more frequent 
occurrence of marginal periodontitis. Due to the closeness of anatomical structures, untreated marginal periodontal diseases may contribute to the formation of pathologies in the apical periodontium, especially those which are caused by the same anaerobic gram negative flora [40,41].

The literature also points out that a larger number of endodontically treated teeth is observed in people exposed to tobacco smoke. Studies of the Portuguese population revealed that the percentage of such teeth in smokers was higher $(4.9 \%)$ in comparison with non-smokers (3.9\%) [10]. According to Segura-Ege et al. [30], the number of teeth undergoing treatment increased with the years of addiction, and decreased over the years since quitting. This is in line with the results of the study of the Łódź population. In smokers, the percentage of teeth with filled root canals was $10.7 \%$, and in non-smokers $9.6 \%$. However, the data on this issue are not unequivocal, as the studies of the Croatian and Swedish populations did not confirm the existence of similar correlations [5,7].

Among the inhabitants of the Łódź region, the effect of smoking on the periodontal status of endodontically treated teeth was also assessed. There were no differences in the prevalence of periapical lesions in smokers compared to non-smokers (37.6\% vs. $35.8 \%$ ). Definitely higher values, but not statistically different, were obtained in Spain $-67 \%$ and 58\%, respectively [30]. Similar results were reported by Peršić et al. [5] who studied the Croatian population, and by Marending et al. [42] who assessed the teeth of Swiss citizens.

The main aim of the endodontic therapy is to maintain the health of the apical periodontium Despite this fact, root canal treatment is one of the most frequently reported tooth specific risk factors for AP [2,3,33]. Epidemiological reviews carried out in different countries indicate a correlation between the quality of root canal treatment and the presence of apical pathologies $[19,22,43,44]$. This was also confirmed by the results of this research. Periapical lesions were found in $80.8 \%$ of the teeth with improperly filled root canals, whereas in the properly treated teeth, the percentage was $15.7 \%$.

In the teeth with incorrect endodontic treatment, the prevalence of AP was similar, equaling $81.4 \%$ among smokers and $80.0 \%$ among non-addicts. Only $15.7 \%$ of the correctly endodontically treated teeth had AP in both groups. Chances of the occurrence of apical pathologies in the teeth with improperly filled canals were higher among patients addicted to tobacco compared to non-smokers (23.46 and 21.56 times higher, respectively).

The literature also emphasizes the influence of non-tooth specific factors that may contribute to an increased risk of AP in smokers. According to the authors, tobacco addiction is correlated with a lower level of education and a poorer socio-economic status. Representatives of these social groups often have lower pro-health awareness and poorer hygiene, and they rarely visit a dentist $[5,45]$.

\section{CONCLUSIONS}

1. Smokers are a group facing an increased risk of apical periodontitis and, therefore, there is a need for an early detection and treatment of caries and its complications in this group of patients.

2. The multifactorial etiology of apical periodontitis indicates the necessity to undertake further studies regarding the effect of smoking on the periapical status.

\section{REFERENCES}

1. Bołtacz-Rzepkowska E, Łaszkiewicz J. Endodontic treatment and periapical health in patients of the Institute of Dentistry in Łódź. Przegl Epidemiol. 2005;59(1):107-15.

2. Frisk F, Hakeberg M. Socio-economic risk indicators for apical periodontitis. Acta Odontol Scand. 2006;64(2):123-8, https://doi.org/10.1080/00016350500469680.

3. Kabak Y, Abbott PV. Prevalence of apical periodontitis and the quality of endodontic treatment in an adult Belarusian population. Int Endod J. 2005;38(4):238-45, https://doi. org/10.1111/j.1365-2591.2005.00942.x. 
4. Marques MD, Moreira B, Eriksen HM. Prevalence of apical periodontitis and results of endodontic treatment in an adult Portuguese population. Int Endod J. 1998;31(3):161-5, https://doi.org/10.1046/j.1365-2591.1998.00136.x.

5. Peršić BR, Jurčević Grgić M, Brumini G, Spalj S, PezeljRibaric S, Brekalo Pršo I. Influence of tobacco smoking on dental periapical condition in a sample of Croatian adults. Wien Klin Wochenschr. 2016;128(7-8):260-5, https://doi. org/10.1007/s00508-015-0910-8.

6. Kirkevang LL, Væth M, Horsted-Bindslev P, Bahrami G, Wenzel A. Risk factors for developing apical periodontitis in a general population. Int Endod J. 2007;40(4):290-9, https:// doi.org/10.1111/j.1365-2591.2007.01224.x.

7. Bergström J, Babcan J, Eliasson S. Tobacco smoking and dental periapical condition. Eur J Oral Sci. 2004;112(2):11520, https://doi.org/10.1111/j.1600-0722.2004.00112.x.

8. Segura-Egea JJ, Martín-González J, Castellanos-Cosano L. Endodontic medicine: connections between apical periodontitis and systemic diseases. Int Endod J. 2015;48(10):933-51, https://doi.org/10.1111/iej.12507.

9. Bergström J, Eliasson S, Dock J. Exposure to tobacco smoking and periodontal health. J Clin Periodontol. 2000;27(1):61-8, https://doi.org/10.1034/j.1600-051x.2000.027001061.x.

10. Rudziński R, Banach J. [Wpływ dymu papierosowego na przebieg i stopień zaawansowania procesu zapalnego w tkankach przyzębia]. Rocz PAM. 2011;57(1):88-95. Polish.

11. Chen CY, Hasselgren G, Serman N, Elkind MS, Desvarieux M, Engebretson SP. Prevalence and quality of endodontic treatment in the Northern Manhattan elderly. J Endod. 2007;33(3):230-4, https://doi.org/10.1016/j.joen.2005. 12.016.

12. Genc Y, Gulsahi K, Gulsahi A. Assessment of possible risk indicators for apical periodontitis in root-filled teeth in an adult Turkish population. Oral Surg Oral Med Oral Pathol Oral Radiol Endod. 2008;106(4):72-7, https://doi. org/10.1016/j.tripleo.2008.06.005.

13. Huumonen S, Suominen AL, Vehkalahti MM. Prevalence of apical periodontitis in root filled teeth:findings from a na- tionwide survey in Finland. Int Endod J. 2017;50(3):229-36, https://doi.org/10.1111/iej.12625.

14. Mukhaimer R, Hussein E, Orafi I. Prevalence of apical periodontitis and quality of root canal treatment in an adult Palestinian sub-population. Saudi Dent J. 2012;24(3-4):149-55, https://doi.org/10.1016/j.sdentj.2012.02.001.

15. De Cleen MJ, Schuurs AH, Wesselink PR, Wu MK. Periapical status and prevalence of endodontic treatment in an adult Dutch population. Int Endod J. 1993;26(2):112-9, https://doi.org/10.1111/j.1365-2591.1993.tb00552.x.

16. Kamberi B, Hoxha V, Stavileci M, Dragusha E, Kuçi A, Kqiku L. Prevalence of apical periodontitis and endodontic treatment in a Kosovar adult population. BMC Oral Health. 2011;11:32, https://doi.org/10.1186/1472-6831-11-32.

17. Matijevic J, Cizmekovic Dadic T, Prpic Mehicic G, Ani I, Slaj M, Jukic Krmek S. Prevalence of apical periodontitis and quality of root canal fillings in population of Zagreb, Croatia: A cross-sectional study. Croat Med J. 2011;52(6):679-87, https://doi.org/ 10.3325/cmj.2011.52.679.

18. Asgary S, Shadman B, Ghalamkarpour Z, Shahravan A, Ghoddusi J, Bagherpour A, et al. Periapical status and quality of root canal fillings and coronal restorations in Iranian population. Iran Endod J. 2010;5(2):74-82.

19. Ilić J, Vujašković M, Tihaček-Šojić L, Milić-Lemić A. Frequency and quality of root canal fillings in an adult Serbian population. Srp Arh Celok Lek. 2014;142(11-12):663-8, https://doi.org/ 10.2298/sarh1412663i.

20. Petersson K, Håkansson R, Håkansson J, Olsson B, Wennberg A. Follow-up study of endodontic status in an adult Swedish population. Endod Dent Traumatol. 1991;7(5):221-5. 21. Loftus JJ, Keating AP, McCartan BE. Periapical status and quality of endodontic treatment in an adult Irish population. Int Endod J. 2005;38(2):81-6, https://doi.org/10.1111/j.13652591.2004.00902.x.

22. Hussein FE, Liew AK, Ramlee RA, Abdullah D, Chong BS. Factors Associated with Apical Periodontitis: A Multilevel Analysis. J Endod. 2016;42(10):1441-5, https://doi.org/10. 1016/j.joen.2016.07.009. 
23. Taşsöker M, Akgünlü F. Radiographic evaluation of periapical status and frequency of endodontic treatment in a Turkish population: a retrospective study. J Istanbul Univ Fac Dent. 2016;50(2):10-6, https://doi.org/10.17096/jiufd.89048.

24. Lupi-Pegurier L, Bertrand MF, Muller-Bolla M, Rocca JP, Bolla M. Periapical status, prevalence and quality of endodontic treatment in an adult French population. Int Endod J. 2002;35(8):690-7, https://doi.org/10.1046/j.1365-2591. 2002.00547.x

25. Ridao-Sacie C, Segura-Egea JJ, Fernández-Palacín A, Bullón-Fernández P, Ríos-Santos JV. Radiological assessment of periapical status using the periapical index: comparison of periapical radiography and digital panoramic radiography. Int Endod J. 2007;40(6):433-40, https://doi.org/10.1111/ j.1365-2591.2007.01233.x.

26. Britto LR, Katz J, Guelmann M, Heft M. Periradicular radiographic assessment in diabetic and control individuals. Oral Surg Oral Med Oral Pathol Oral Radiol Endod. 2003;96(4):449-52, https://doi.org/10.1016/s1079-2104(03)00 034-9.

27. Molander B, Ahlqwist M, Gröndahl HG, Hollender L. Comparison of panoramic and intraoral radiography for the diagnosis of caries and periapical pathology. Dentomaxillofac Radiol. 1993;22(1):28-32, https://doi.org/10.1259/ dmfr.22.1.8508938.

28. Duncan HF, Ford TRP. The potential association between smoking and endodontic disease. Int Endod J. 2006;39(11): 843-54, https://doi.org/10.1111/j.1365-2591.2006.01141.x.

29. Kirkevang LL, Wenzel A. Risk indicators for apical periodontitis. Community Dent Oral Epidemiol. 2003;31(1):5967, https://doi.org/10.1034/j.1600-0528.2003.00032.x.

30. Segura-Egea JJ, Jimenez-Pinzon A, Rios-Santos JV, Velasco-Ortega E, Cisneros-Cabello R, Poyato-Ferrera MM. High prevalence of apical periodontitis amongst smokers in a sample of Spanish adults. Int Endod J. 2008;41(4):310-6, https://doi.org/10.1111/j.1365-2591.2007.01365.x.

31. Berlinck T, Tinoco JM, Carvalho FL, Sassone LM, Tinoco EM. Epidemiological evaluation of apical periodontitis prevalence in an urban Brazilian population. Braz Oral Res. 2015;29(51):1-7, https://doi.org/10.1590/1807-3107BOR2015.vol29.0051.

32. Bołtacz-Rzepkowska E, Pawlicka H. [Ocena jakości leczenia endodontycznego poszczególnych zębów za pomocą zdjęć rentgenowskich]. J Stoma. 2004;57(2):92-8. Polish.

33. Oginni AO, Adeleke AA, Mejabi MO, Sotunde OA. Risk factors for apical periodontitis sub-urban udult population. Niger Postgrad Med. 2015;22(2):105-9.

34. Murtomaa H, Al Zaabi F, Morris RE, Metsäniitty M. Caries experience in a selected group of children in Kuwait. Acta Odontol Scand. 1995;53(6):389-91, https://doi.org/10.3109/ 00016359509006006.

35. Correia-Sousa J, Raquel Madureira A, Fontes Carvalho M, Moura Teles A, Pina-Vaz I. Apical periodontitis and related risk factors: Cross-sectional study. Rev Porte Stomatol Med Dent Cir Maxilofac. 2015;56(4):226-32, https://doi. org/10.1016/j.rpemd.2015.08.004.

36. Rodriguez FR, Taner B, Weiger R, Walter C. Is smoking a predictor of apical periodontitis? Clin Oral Investig. 2013; 17(8):1947-55, https://doi.org/10.1007/s00784-012-0893-Z.

37. Palmer RM, Wilson RF, Hasan AS, Scott DA. Mechanisms of action of environmental factors - tobacco smoking. J Clin Peridontol. 2005;32(6):180-95, https://doi.org/10.1111/ j.1600-051X.2005.00786.x.

38. Axelsson P, Paulander J, Lindhe J. Relationship between smoking and dental status in 35-, 50-, 65-, and 75-year-old individuals. J Clin Periodontal. 1998;25(4):297-305, https:// doi.org/10.1111/j.1600-051x.1998.tb02444.x.

39. Locker D. Smoking and oral health in older adults. Can J Public Health. 1992;83(6):429-32.

40. Jansson L, Ehnevid H, Lindskog S, Blomlöf L. The influence of endodontic infection on progression of marginal bone loss in periodontitis. J Clin Periodontol. 1995;22(10):729-34, https://doi.org/10.1111/j.1600-051x.1995.tb00254.x.

41. Stassen IG, Hommez GM, De Bruyn H, De Moor RJ. The relation between apical periodontitis and root-filled teeth in patients with periodontal treatment need. Int Endod J. 
2006;39(4):299-308, https://doi.org/10.1111/j.1365-2591.2006. 01098.x.

42. Marending M, Peters OA, Zehnder M. Factors affecting the outcome of orthograde root canal therapy in a general dentistry hospital practice. Oral Surg Oral Med Oral Pathol Oral Radiol Endod. 2005;99(1):119-24, https://doi.org/10.1016/ j.tripleo.2004.06.065.

43. Frisk F, Hugosson A, Kvist T. Is apical periodontitis in root filled teeth associated with the type of restoration? Acta Odontol Scand. 2015;73(3):169-75, https://doi.org/10.3109/ 00016357.2014 .950182$.
44. Tronstad L, Asbjørnsen K, Døving L, Pedersen I, Eriksen HM. Influence of coronal restorations on the periapical health of endodontically treated teeth. Endod Dent Traumatol. 2000;16(5):218-21.

45. Krall EA, Abreu Sosa C, Garcia C, Nunn ME, Caplan DJ, Garcia RI. Cigarette smoking increases the risk of root canal treatment. J Dent Res. 2006;85(4):313-7, https://doi. org $/ 10.1177 / 154405910608500406$.

This work is available in Open Access model and licensed under a Creative Commons Attribution-NonCommercial 3.0 Poland License - http://creativecommons.org/ licenses/by-nc/3.0/pl/deed.en. 